\title{
The Influence Of Transformational Leadership, Job Satisfaction, Motivation And Compensation On Mathematics School TeacherPerformance
}

\author{
Angga Pratama ${ }^{a}$, Rahmi Andini Syamsuddin ${ }^{\mathrm{b}}$, Whina Ratnawatic, Faisal ${ }^{\mathrm{d}}$, Vidya Amalia Rismanty ${ }^{\mathrm{e}}$, Denok \\ Sunarsi ${ }^{\text {f }}$ \\ a,b,c,d,e,f, Universitas Pamulang, Tangerang Selatan, Banten, Indonesia \\ Coresponding Email: Angga Pratama / dosen02155@unpam.ac.id
}

Article History: Received: 10 November 2020; Revised 12 January 2021 Accepted: 27 January 2021; Published online: 5 April 2021

\begin{abstract}
The purpose of this study is to describe the influence of transformational leadership on job satisfaction, the effect of compensation on job satisfaction, the influence of work motivation on job satisfaction,the influence of transformational leadership, compensation and work motivation together on job satisfaction This research is a quantitative research. The population in this study are Mathematic teachers. The sample of the study was 75 teachers.Data collection was done by using questionnaire method. Data analysis technique used is regression technique supported by T test, path analysis test and classical assumption test with SPSS 20.00 for windows application. The result of data analysis with significance 0,05 shows that there is no positive and significant influence between transformational leadership to job

satisfaction. There is no positive and significant influence between compensation on job satisfaction. There is a positive and significant influence between work motivation on job satisfaction. And There is a positive and significant influence of transformational leadership, compensation and work motivation on job satisfaction at mathematics Teachers
\end{abstract}

Keywords: Transformational Leadership, Compensation, Work Motivation and JobSatisfaction.mathematics Teachers

\section{Introduction}

According Putra et al. (2021); Praditya, R. A. (2020)Job satisfaction is an employee's emotional state that occurs or where there is no meeting point between the value of remuneration for employees and the company or organization with the level of remuneration that is desired by the employee concerned. received accordingly. According Putra et al. (2021); Praditya, R. A. (2020)Job satisfaction is basically something that is individual, each individual has a different level of satisfaction according to the value system that applies to him. Job satisfaction is an emotional statefun or unpleasant where employees see their work . Leadership basically contains the meaning as an embodimentthe behavior of a leader which concerns his ability to lead. Effective leadership will be able to encourage organizational motivationproductivity, loyalty and satisfaction of subordinates or members of the organization increases. According to Kotamena et al. (2020); Novitasari et al.(2021) states that humans are essentially leaders and eachhumans will be held accountable for their future leadership. Humans as leaders are at least able to lead themselves. Every organization must have a leader, who is ideally obeyed and respected by his subordinates.

Compensation must also affect other aspects to increase work motivation which will have an impact on employee job satisfaction. According to Asbari et al (2020); Budi Hartono et al.(2020); Tri Suci Rokhani (2020)) states that compensation is divided into two, there are direct compensation or indirect compensation, compensation is all income in the form of money, direct or indirect goods received by employees as compensation for services provided to companies. Motivation is an incentive to desire and a driving force for the will to worka person, each motivation has a specific goal to be achieved According to Purwanto et al (2020); Suryani et al.(2020)describing motivation is a problem related to how to encourage someone's passion to want to work hard by giving all the ability to realize organizational goals.

According to Kotamena et al. (2020); Novitasari et al.(2021) Transformational leadership is the ability to inspire and motivate followers to achieve greater results than originally planned and for internal rewards. According to Purwanto et al (2020);Suryani et al.(2020)Leadership also has an important effect on work motivation and job satisfaction. As the opinion of Maryama, Hitam, Torsiman, and Balakrishnan in the bookEmed Taryaman (2016: 16), that the ideal influence where subordinates believe and will bond emotionally with the leader, here the leader becomes a model and behaves encouragingly by giving trust, appreciation and selfconfidence,or if there is no meeting point between the value of remuneration for employees and the company or organization with the level of remuneration that is desired by the employee concerned, this is intended if an 
employee feels that the receipt of work services and the benefits received are appropriate, the employee will feel satisfaction workCompensation is a reward or reward for workers who have contributed in realizing the goals of the company, through activities called work (Hadari Nawawi 2005: ). According to Sihite et al (2020); Supratman et al (2021); Suprapti et al . (2020)The purpose of providing compensation to employees is one other aspect of increasing work motivation which will have an impact on employee job satisfaction, Hadari Nawawi (2005: 315) describes compensation as an award or reward for workers who have contributed to realizing its goals, through activities called work. According to Sihite et al (2020); Supratman et al (2021); Suprapti et al . (2020)Compensation that is given to employees fairly and appropriately for work performance and services that have been issued to organizational goals for the achievement of organizational goals is intended to stimulate the desire and driving force of an employee's will to work as motivation for work. In other words, compensation is given to employees as a form of company concern to improve employee job satisfaction at work.

In general, work motivation is a feeling that drives the will to work. According to Purwanto et al (2020); Suryani et al.(2020)motivation is an incentive to desire and the driving force of a person's willingness to work, each motivation has a specific goal that wants achieved and describing motivation is a problem related to how to encourage someone's passion to want to work hard by giving all the capabilities to realize organizational goals. Motivationvery much needed in an organization because with this motivation it is expected that every individual in an organization can work hard and enthusiastically to achieve high work productivity. Motive can be interpreted as a driving force that moves people to behave and act with certain goals. The motivation of an employee at work, with what the leadership gives to employees in their work.

Because, motivation is one of the influences that can influence employees to do their job better. So that when employee motivation is achieved thenwill affect the employee's satisfaction. Transformational leadership has an effect on job satisfaction. According to Purwanto et al (2020);Suryani et al.(2020)the ideal influence where subordinates believe in the leader and will be emotionally attached to the leader, here the leader becomes a model and behaves encouragingly by giving trust, appreciation and self-confidence, to the leader and will be emotionally tied to a meeting point between the value of reciprocationemployment services for employees and companies or organizations with a level of remuneration that is desired by the employee concerned, this is meant if a personEmployees feel that the receipt of work services and rewards (compensation), which is received according to the employee's meal, According to Sihite et al (2020); Supratman et al (2021); Suprapti et al . (2020)job satisfaction is the key to driving morale, discipline, and employee performance in supporting the realization of company goals. However, creating satisfaction is not easy, there are several factors that contribute to job satisfaction, from many factors including leadership. transformational, work motivation and compensation.

The hypotheses in this study are:

$\mathrm{H} 1$ : the effect of transformational leadership (X1) on job satisfaction (Y)

$\mathrm{H} 2$ : the effect of compensation (X2) on job satisfaction (Y)

H3: the effect of work motivation (X3) on job satisfaction (Y)

H4: the effect of transformational leadership (X1), compensation (X2) and work motivation on

Satisfaction (Y) 


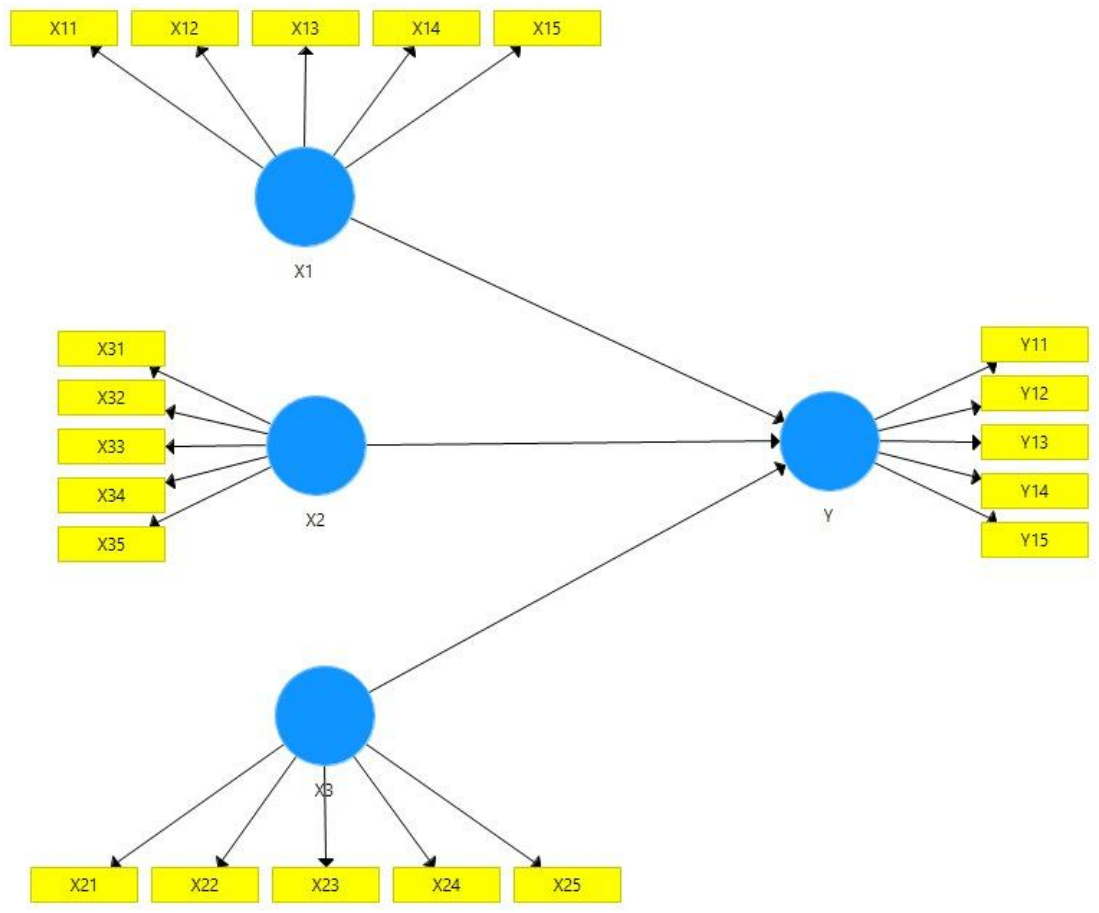

Fig 1. Research Model

\section{Method}

The nature of the research used is quantitative research According to Kotamena et al. (2020); Novitasari et al.(2021) quantitative research methods can be interpreted as research methods based on the philosophy of positivism, used to research on certain populations or samples. The population in this study were 75 mathematics teachers. Sampling using a census technique which is a data collection technique that is taken by collecting the information needed from all related population units contained in the population. The census is a truth that can be justified and has a scientific level that tends to be higher than thatother techniques (Wiyono, 2011). By considering efficiency and effectiveness, this census technique is carried out if the population data is relatively not too large, if the population data is large, it will require a lot of time, effort, and money. With this statement, because the population is not greater than 100 employees, the authors take a sample of $100 \%$ of the total population, which is 75 math teacher.

\section{Results And Discussion}

The results of the normality test using the Kolmogorov-Smirnov test show the Asymp value. Sig. (2 tailed) of 0.211 whose value is greater than 0.05 . This is a whole of the two

normally distributed data.The multicoloniearity test results show that all independent variables have a VIF value less than 10 and a tolerance greater than 0.1 , thus the multiple regression model used in this study does not contain multicollinearity symptoms. The results of the heteroscedasticity test show that none of the independent variables statistically significant affect the dependent variable having a significant value greater than 0.05 . So it can be concluded that the regression model is not

contains heteroscedasticity

H1: Transformational Leadership Has No Effect on Job Satisfaction. The results showed that transformational leadership did not have a positive and significant effect on job satisfaction of mathematics teachers. These results are supported by regression analysis with the results of the t-value is greater than the t-table $(0.254<1.68107)$, with a probability value $(0.843)$ greater than the significant level of 0.05 , thus, it means that transformational leadership is not has a significant positive effect on job satisfaction in mathematics teachers. The results of this study are in line with Putra et al. (2021); Praditya, R. A. (2020); Asbari et al (2020); Budi Hartono et al. (2020); Tri Suci Rokhani (2020) that Transformational Leadership Has No Effect on Job Satisfaction

H2: Compensation Has No Effect on Job Satisfaction 
The results of the second hypothesis test in this study indicate that compensation has no positive and significant effect on job satisfaction of mathematics teachers in the Operations Department, after statistical tests are carried out with the results of the t-count value smaller than the t-table $(1.064<1.68107)$, with a probability value ( 0.243) is largerfrom the significant level of 0.05 thus, the second hypothesis is rejected.The results of this study are in line with Supratman et al (2021); Suprapti et al. (2020); Purwanto et al (2020); Suryani et al. (2020); Asbari et al (2020); Budi Hartono et al. (2020); Tri Suci Rokhani (2020) that Compensation Has No Effect on Job Satisfaction

\section{H3: Work Motivation Has No Effect on Job Satisfaction}

The results of the triple hypothesis test in this study indicate that work motivation does not have a positive and significant effect on job satisfaction of mathematics teachers, after a statistical test is carried out with the results of the t-count value smaller than t-table $(1.069<1.68107)$, with a probability value. $(0.291)$, which is greater than the significant level of 0.05 , thus, it means that the employees' work motivation is ownedmathematics teacher is not yet in good category. The results of this study are in line with Purwanto et al (2020); Suryani et al. (2020); Asbari et al (2020); Budi Hartono et al. (2020); Tri Suci Rokhani (2020) that that work motivation does not have a positive and significant effect on job satisfaction of mathematics teachers.

H4: Transformational Leadership, Compensation and Work Motivation Simultaneously Influence Job Satisfaction. 'Transformational leadership, compensation and work motivation have a positive effect

and is significant simultaneously on the job satisfaction of mathematics teachers. This shows if leadershiptransformational, compensation and work motivation are increased together, it will increase employee job satisfaction.The results of this study are in line with Putra et al. (2021); Praditya, R. A. (2020); Kotamena et al. (2020); Suprapti et al. (2020); Purwanto et al (2020); Suryani et al. (2020); Asbari et al (2020); Budi Hartono et al. (2020); Tri Suci Rokhani (2020) that Transformational leadership, compensation and work motivation have a positive effectand is significant simultaneously on the job satisfaction of mathematics teachers.

\section{Conclusion}

From the results of the analysis, a conclusion is obtainedThere is a positive influence between transformational leadership on job satisfaction.But it is not significant. There is a positive influence between compensation on job satisfaction. But notsignificant . There is a positive influence between work motivation and job satisfaction. But notsignificant . Simultaneously there is a positive and significant effect of transformational leadership,compensation and work motivation on job satisfaction

\section{References}

AA. Prabu Mangkunegara,2008. Manajemen Sumber Daya Manusia Perusahaan. Remaja Rosdakarya, Bandung. Arikunto. (2010). Prosedur Penelitian: Suatu Pendekatan Praktek. Jakarta: Rineka Cipta.

Asbari, M. (2020). Is Transformational Leadership Suitable for Future Organizational Needs?. INTERNATIONAL JOURNAL OF SOCIAL, POLICY AND LAW, 1(1), 51-55. https://doi.org/10.8888/ijospl.v1i1.17

Asbari, M., Santoso, P. B., \& Prasetya, A. B. (2020). Elitical And Antidemocratic Transformational Leadership Critics: Is It Still Relevant ? ( A Literature Study). INTERNATIONAL JOURNAL OF SOCIAL, POLICY AND LAW, 1(1), 12-16. https://doi.org/10.8888/ijospl.v1i1.10

Asbari, M., Dylmoon Hidayat, D., \& PURWANTO, A. (2021). Managing Employee Performance: From Leadership to Readiness for Change. International Journal of Social and Management Studies, 2(1), 74-85. https://doi.org/10.5555/ijosmas.v2i1.12

Astuti, R. Y., Sa'adah, N., Rahmawati, S. D., Astuti, J. P., Suprapti, S., \& Sudargini, Y. (2020). Impact of Leadership Style, Work Motivation, Organization Culture Toward Satuan Polisi Pamong Praja Work Performance. Journal of Industrial Engineering \& Management Research, 1(3), 49-64. https://doi.org/10.7777/jiemar.v1i3.56

Budi Hartono, \& Maksum, I. (2020). The Importance of Changing Management Styles in The Digital Age: The Importance of Changing Management Styles in The Digital Age. Journal of Industrial Engineering \& Management Research, 1(3), 148-154. https://doi.org/10.7777/jiemar.v1i3.75

Danang \& Danang. 2010. Manajemen Operasional. Cet.1. CAPS, Yogyakarta

Elizabeth Satriowati, Patricia Dhiana Paramita Dan Leonardo Budi Hasiholan (2016),

Pengaruh Gaya Kepemimpinan Transformasional, Kompensasi Dan Komunikasi

Terhadap Kinerja Karyawan Dengan Kepuasan Kerja Sebagai Variabel Mediasi

Pada Laudry Elephant. jurnal.unpand.ac.id 16,3, 2015.

Google. Dinsos. 05 Desember 2017. https://id.dinsos.jogjaprov.go.id/profil-dinas-sosial-diy-

Ghozali, Imam. (2012). Aplikasi Analisis Multivariate dengan Program IBM SPSS 20.

Semarang: Badan Penerbit \pm Universitas Diponegoro. 
Hariandja, Marihot Tua Efendi. (2007). Manajemen Sumber Daya Manusia : Pengadaan,

Pengembangan, Pengkompensasian, dan Peningkatan Produktivitas Pegawai. Jakarta

: Grasindo. Jurnal Ekobis Dewantara Vol. 1 No. 7Juli 201890

Hasibuan. 2008, Manajemen Sumber Daya Manusia, Edisi Revisi, Jakarta: Bumi Aksara.

Husaini, Usman.2009. Metodologi Penelitiam Sosial.Jakarta : Bumi Aksara

Hutagalung, L., PURWANTO, A., Prasetya, A. B., \& Pramono, R. (2020). TRANSFORMATIONAL LEADERSHIP FOR ENTERING INDUSTRIAL REVOLUTION 4.0 AS COMPARED WITH HUMANE LEADERSHIP AND “U” THEORY. INTERNATIONAL JOURNAL OF SOCIAL, POLICY AND LAW, 1(1), 73-78. https://doi.org/10.8888/ijospl.v1i1.20

Hutagalung, L., PURWANTO, A., \& Prasetya, A. B. (2020). The Five Leadership Style in Time of Pandemic Covid-19 throughout Industrial Revolution 4.0 as compared to Humane Leadership. INTERNATIONAL JOURNAL OF SOCIAL, POLICY AND LAW, 1(1), 79-87. https://doi.org/10.8888/ijospl.v1i1.21

Kadarisman, M. 2012. Manajemen Pengembangan Sumber Daya Manusia, Edisi Pertama,

Cetakan pertama, Rajawali Press, Jakarta,

Kotamena, F., Senjaya, P., \& Prasetya, A. B. (2020). A Literature Review: Is Transformational Leadership Elitist and Antidemocratic?. INTERNATIONAL JOURNAL OF SOCIAL, POLICY AND LAW, 1(1), 36-43. https://doi.org/10.8888/ijospl.v1i1.15

Novitasari, D., Siswanto, E., PURWANTO, A., \& Fahmi, K. (2021). Authentic Leadership and Innovation: What is the Role of Psychological Capital?. International Journal of Social and Management Studies, 1(1), 1-21. https://doi.org/10.5555/ijosmas.v1i1.1

Maineldi, et all. 2014. Pengaruh kompensasi dan lingkungan kerja terhadap loyalitas

karyawan pada PT. Jatim Jaya Perkasa Kebun Banjar Balam Indragiri Hulu.

Universitas Riau, Sumatera. Vol. 1,No. 2.

Ngatemin Wanti Dan Arumwanti (2012) Pengaruh Kompentensi Dan Kompensasi Terhadap

Motivasi Kerja Karyawan Hotel Di Kabupaten Karo Provinsi Sumatera

Utara.jurnal.umsu.ac.id 2,9,2012

Risambessy Aghustina, Swasto Bambang, Thoyib Armanu dan Astuti Siti Endang., 2011.Pengaruh Gaya Kepemimpinan Transformasional, Motivasi, Burnout terhadap

Kepuasan Kerja dan Kinerja Karyawan. Vol. 9, No. 3. https://ojs.unud.ac.id

Robbins, Stephen P. (2008). Perilaku Organisasi, Konsep Kontroversi, Aplikasi. Jilid 1 Edisi

Bahasa Indonesia. Pren hall Indo.

Purwanto, A., Kusumaningsih, S. W., \& Prasetya, A. B. (2020). Did Transformational Leadership Elitist and Antidemocratic? A Literature Review. INTERNATIONAL JOURNAL OF SOCIAL, POLICY AND LAW, 1(1), 1-11. https://doi.org/10.8888/ijospl.v1i1.1

Purwanto, A., Asbari, M., Hartuti, H., Setiana, Y. N., \& Fahmi, K. (2021). Effect of Psychological Capital and Authentic Leadership on Innovation Work Behavior. International Journal of Social and Management Studies, 2(1), 1-13. https://doi.org/10.5555/ijosmas.v2i1.4

Putra, A. S., Waruwu, H., Asbari, M., Novitasari, D., \& Purwanto, A. (2021). Leadership in the Innovation Era: Transactional or Transformational Style?. International Journal of Social and Management Studies, 1(1), 8994. https://doi.org/10.5555/ijosmas.v1i1.10

Praditya, R. A. (2020). Leadership, Work Motivation, Competency, Commitment and Culture: Which influences The Performance of Quality Management System in Automotive Industry?. Journal of Industrial Engineering \& Management Research, 1(1), 53-62. https://doi.org/10.7777/jiemar.v1i1.27

Simamora, H. (2009). Manajemen Sumber Daya Manusia. Yogyakarta : STIE YKPN.

Sugiyono. 2012. Metode Penelitian Kuantitatif Kualitatif dan R\&D. Bandung: Alfabeta

Sihite, O. B., Andika, C. B., \& Prasetya, A. B. (2020). A Literature Review: Does Transformational Leadership impact and Effective in the Public Bureaucratic. INTERNATIONAL JOURNAL OF SOCIAL, POLICY AND LAW, 1(1), 44-50. https://doi.org/10.8888/ijospl.v1i1.16

Supratman, O. V. ., Entang, M., \& Tukiran, M. (2021). The Relationship of Charismatic Leadership, Employee Personality, and Employee Performance: Evidence from PT. Karya Abadi Luhur. International Journal of Social and Management Studies, 2(2), 17-41. https://doi.org/10.5555/ijosmas.v2i2.15

Suprapti, S., Asbari, M., Cahyono, Y., \& Mufid, A. (2020). LEADERSHIP STYLE,ORGANIZATIONAL CULTURE AND INNOVATIVE BEHAVIOR ON PUBLIC HEALTH CENTER PERFORMANCE DURING PANDEMIC COVID-19. Journal of Industrial Engineering \& Management Research, 1(2), 76-88. https://doi.org/10.7777/jiemar.v1i2.42

Suryani, P., Cahyono, Y., \& Utami, B. D. (2020). Pengaruh Motivasi Dan Gaya Kepemimpinan Terhadap Produktivitas Kerja Karyawan Produksi di PT Tuntex Garment Indonesia. Journal of Industrial Engineering \& Management Research, 1(1), 70-82. https://doi.org/10.7777/jiemar.v1i1.28 
Sunyoto, D. 2012. Manajemen Sumber Daya Manusia. Yogyakarta : CAPS

Sutrisno, Edy. 2011. Manajemen Sumber Daya Manusia. Edisi 1. Cetakan Kedua. Prenada

Media Group. Jakarta.

Taryaman, E. 2016. Manajemen Sumber Daya Manusia: Kumpulan Teori MSDM yang

dilengkapi dengan Hasil Penelitian pada instansi. Yogyakarta: Deepublish, edisi

pertama.

Veithzal Rivai. (2010). Manajemen Sumber Daya Manusia Untuk Perusahaan: Dari Teori Ke Praktik. Jakarta: PT Raja Grafindo Persada.

Vivi Ariyani 2009 Pengaruh Kepemimpinan Transformasional Terhadap Motivasi Kerja Dosen Pada Universitas Yang Berada Di Kota Madiun https://jurmafis.untan.ac.id/.

4,9, 2016.

Wiyono, Gendro, 2011. Merancang Penelitian Bisnis Dengan Alat SPSS 17.0 \$ Smart PLS

20. STM YKPN. Yogyakarta 